\begin{tabular}{|c|c|c|}
\hline & $\begin{array}{c}\text { International Journal of Current Research in } \\
\text { Biosciences and Plant Biology }\end{array}$ \\
\hline EXCELLENT \\
PUBLISHERS
\end{tabular}

\title{
Effect of Different Sowing Date on Yield Losses in Ten Winter Wheat Cultivars Caused by Aphid Infestation
}

\author{
Sardar Said Amin* and Faraidun Muhammad Hama Faraj
}

Department of Horticulture, Faculty of Agricultural Sciences, University of Sulaimani, Sulaimani, Iraq

*Corresponding author.

\begin{tabular}{|c|c|}
\hline Abstract & Article Info \\
\hline $\begin{array}{l}\text { Present experiment was conducted to study the impact of aphid population aphids on ten } \\
\text { different varieties/ lines of winter wheat planted at three different sowing dates. Samplings } \\
\text { were done weekly from } 10 \text { randomly taken plants from each planting. Aphid population } \\
\text { increased gradually during January in the first, second sowing dates and during February } \\
\text { in the third sowing date. Aphid population increased exponentially from end of February } \\
\text { to end of March and declined from end of March to the beginning of April on wheat } \\
\text { planted on all these dates. Mean aphid population was higher on second sowing date as } \\
\text { compared to that on first and third sowing dates. The second sowing date found to be } \\
\text { more favorable for aphids populations in wheat fields in the study area. Last week of } \\
\text { February was found to be very favorable for aphids in wheat fields in this study. Third } \\
\text { week of February was found to be the most suitable period for the presence of aphid in } \\
\text { wheat crop. The results of the present study showed strong differences in aphid infestation } \\
\text { density probably because of different weather conditions. The mean number of aphids per } \\
\text { plant was higher on wheat line Sham6 ( } 23,33 \text { aphids per plant), which was followed by } \\
\text { Aras ( } 19.67 \text { aphids per plant), Sabir beg (19.33 aphids per plant), Adana (16.33 aphids per } \\
\text { plant), Tammoz ( } 16.00 \text { aphids per plant), Holandy (11.33 aphids per plant), Mariboss } \\
\text { ( } 7.67 \text { aphids per plant), Ritmo ( } 7.33 \text { aphids per plant), Hereford ( } 6.33 \text { aphids per plant) } \\
\text { and Skalmeje (4.67 aphids per plant). More precise data relating the effects of aphid } \\
\text { population on the thousand kernel weight (TKW) in wheat varieties have been obtained } \\
\text { from different sowing dates. Based on these data, TKW were significantly and negatively } \\
\text { affected by aphid population in the cultivar Aras and Sham6 which were assessed as } \\
\text { susceptible, whereas the cultivars, Skalmeje, Ritmo and Hereford as resistant to aphid } \\
\text { population. On the basis of experimental results it is concluded that different sowing dates } \\
\text { of wheat crops could provide additional information about selection of both resistant and } \\
\text { suscentible wheat cultivars to anhid nonulation }\end{array}$ & $\begin{array}{l}\text { Key words } \\
\text { Aphid population } \\
\text { Sowing date } \\
\text { Winter wheat } \\
\text { Yield loss }\end{array}$ \\
\hline
\end{tabular}

\section{Introduction}

Wheat (Triticum aestivum L.) is a cereal grain originally from the Levant region but now cultivated worldwide. In
2016, world production of wheat was 749 million tons, making it the second most-produced cereal after maize (1.03 billion tons), with more than rice (499 million tons). Since 1960, world production of wheat and other 
grain crops has tripled and is expected to grow further through the middle of the 21 st Century (Godfray et al., 2010; James, 2014). Winter wheat plays an important role in Iraq's food security. Wheat, the major grain is planted at the beginning of October until the end of November. Harvest usually begins in May and continues through June. In recent years wheat production increased. USAD estimated the wheat crop harvest in 2014 (market 2014/15) at a record 3,5 million metric tons due to high incentives to plant and very good weather conditions (William, 2015).

Aphids are major agricultural pests, as over 250 species feed on crop plants and can also vector viruses (Blackman and Eastop, 2000), leading to losses in crop production estimated to be hundreds of millions of dollars each year (Oerke et al., 1994).Aphids cause substantial yield losses by direct effects of their feeding as a vector of several plant viruses (Dixon, 1987; Holmes et al., 1991). Aphid population affects the produce adversely (Wratten and Redhead, 1976; Girma et al., 1993) by feeding and causing $35-40 \%$ yield losses directly (Kiechefer and Gellner, 1992) and 20$80 \%$ yield losses indirectly by transmission of virus and by development of mould (brown rust) on their honey dew (Marzochi and Nicoli, 1991; Rossing et al., 1994; Wood et al., 1988), it sucks the sap and injects the toxin into the plant and interferes with the grain formation (Holmes et al., 1991).

Aphid colonies can grow very rapidly due to a short generation time. During the asexual phase of the lifecycle females can be carrying both their own daughters and embryos developing within the daughters (Blackman and Eastop, 2000). Aphids are small in size (1-10 $\mathrm{mm})$ and have distinguishing features of a long pair of antennae, a proboscis that they use to pierce the plant and suck phloem sap through, and siphunculi which are located on the dorsal fifth abdominal segment and consist of a pair of upward-pointing tubes (Brisson and Stern, 2006). Aphids can disperse either over short or medium distances (several meters to several kilometers) by active flight (Loxdale et al., 1993; Llewellyn and Loxdale 2003) or over long distances by passive flight, lifted by wind streams (Loxdale et al., 1985; Simon et al., 1999).

Aphid populations are subject to large outbreaks governed by the conjunction of favorable climatic and/or biotic conditions (Kindler et al., 2007) because, firstly, of their high reproductive rate due to parthenogenesis and viviparity and, secondly, of their high dispersive potentialities due to winged morphs production (Wood et al., 1988).

Several species of aphid occur on cereal crops, including bird-cherry aphid (Rhopalosiphum padi), cereal-leaf aphid (Rhopalosiphum maidis), fescue aphid (Metopolophium festucae), grain aphid (Sitobion avenae) and rose/grain aphid (Metopolophium dirhodum). Bird-cherry aphid and grain aphid are both important vectors of barley yellow dwarf virus (Girma et al., 1993; Thomas and Butts, 1990). Grain aphid is a serious pest having a wide host range of at least 60 plant species including wheat, barley, sorghum and corn (Kindler et al., 1984; Bowling et al., 1998).

Cereal aphids have been the main pest of winter wheat during the last several years. As a result, regular treatments of large areas are necessary to prevent yield losses (Castro, 1980). As economic thresholds are low, frequent applications are needed which contradict the use of natural enemies. A strategy has to be developed to include optimal timing and reduction of side effects of insecticides to non-target organisms, particularly beneficial arthropods like aphid antagonists (Hinz and Daeber, 1976). Cereal leaf aphid, which is restricted to grasses and cereals, is rarely found on wheat but is sometimes numerous on fescue aphids, occurs mainly on grasses (Acreman and Dixon, 1985).

In many areas aphids were considered the most important insect pest of winter wheat fields (Dixon, 1987; Castro, 1980; Bowling et al., 1998). The incidence of aphids has also been reported to be significantly different on different cultivars of wheat (Hinz and Daeber, 1976). On wheat, summer infestations by grain aphid or rose/grain aphid can cause substantial yield loss. When present on the crop before flowering, the aphids damage the crop by reducing the numbers of grains in the ear; when present from flowering to the end of the grain-filling period, the aphids reduce the size of the grain. Grain aphids infest both the ear and the upper leaves, whereas rose/grain aphids remain on the underside of the leaves (Blackman and Eastop, 2000).

The wheat crop is generally infested with aphids during the growth stages when both the adults and nymphs take a heavy toll by sucking cell sap which reduces the vitality of the plants (Castro, 1980).

Population density of aphids depends on the abiotic factors (Wains et al., 2008). It depends also on the wheat 
crop stages (Rios and Conde, 1986; Robe et al., 1989) because their pre-reproductive, reproductive and postreproductive periods and fecundity are significantly affected by crop varieties (Dixon, 1987). The abundance of aphid adversely affects the nitrogen and protein contents, weight of 1000 grains, number of grains per ear (Dixon, 1987; Castro, 1980) and results in decrease in carbon assimilation rate, transpiration and total chlorophyll (Castro, 1980) and reduction in plant biomass (Holmes et al., 1991).

It has been suggested that early maturing varieties would avoid outbreaks of aphids (Hinz and Daeber, 1976). Aphid infestation increases on late plantings of wheat and reduces the yield as compared to normal planting (Acreman and Dixon, 1985). Late sown wheat crop may be badly damaged, if the cool and time-to-time cloudy weather continues till the end of March (Holmes et al., 1991). Potential for aphid infestation can be reduced by sowing wheat early in the season (Acreman and Dixon, 1985). Significantly low aphid infestation on early sown wheat varieties has been reported (Xiong, 1990).

Here we focused on the greenbug, Schizaphis graminum (Rondani), which is a worldwide pest of graminaceous plants that has been recognized as a major pest of small grains in North, Central and South America, Europe, Africa, the Middle East and Asia (Burde et al., 2006; Kindler et al., 2003; Kindler et al., 2002). Both winter and spring grains can be severely damaged by greenbug Populations, which has a strong preference for the ear and feeds on the rachis and on the base of the spikelets, which usually leads to substantial yield loss (Dixon, 1987; Hays et al., 1999). It has been reported that a few locally bread wheat cultivars were highly preferred and susceptible to green bug, S. graminum (Aphididae: Homoptera) infestation under laboratory condition (Hussein and Al-neami, 2013). Several studies have already been conducted to detect at least one relatively resistant variety to control aphids in order to decrease insecticide applications (Roberts and Foster, 1983; Papp and Mesterhazy, 1993).

The aim of this study is to:

1. Determine the effect of sowing dates on population of aphids, on different wheat varieties/lines of wheat.

2. Evaluation of the yield reduction in thousand kernel weight in wheat crop due to the infestation of aphids.

\section{Materials and methods}

\section{Field experiments}

Field experiments were conducted at the Farm of Department of Horticulture, Faculty of Agricultural Sciences, University of Sulaimani, Sulaimani, Iraq during 2015-2016.

\section{Cultivars}

The following Ten winter wheat varieties / lines of Skalmeje, Hereford, Ritmo, Mariboss, Aras, Sham6, Adana, Holandy and Sabir beg were sown on three different times 28/11/2015, 19/12-2015 and 17/1-2016.

\section{Experimental design}

The completely randomized block design (CRBD) was used in designing the experiments with three replicates for three planting dates with 15days interval. Each replicate contains one line of $2 \mathrm{~m}$ length. In case of inadequate length of the experiment site each replicate can be arranged with two lines of $1 \mathrm{~m}$ each.

\section{Aphid sampling}

The data of aphids were recorded weekly during the whole experimental period (From January to April 2016). Number of aphid was counted visually on five tillers per plant on leaves, stem and later stage on spike /plot selected randomly. Data regarding (RH\% and ${ }^{\circ} \mathrm{C}$ ) was recorded from Meteorological center in Bakrajo.

\section{Yield losses estimation and thousand grain weight}

On reaching maturity the wheat varieties/lines were harvested on 12.5.2016. Each plot was harvested and threshed separately to obtained yield/plot. Random wheat grain samples were taken from each plot for counting thousand grains and these grains were weight separately on electric balance and compared later.

\section{Analyses of data}

The data were subjected to statistical analysis using SAS Statistical Software (SAS Institute INC). ANOVA was made to compare the yield losses and thousand grain weight losses, after counting percentage yield losses (LSD $p \leq 0.05$ ). Hypotheses were rejected at $p \leq 0.05$. 


\section{Results}

\section{Reaction of wheat varieties to aphid population under different sowing dates}

Aphid infestation started in the $1^{\text {st }}$ week of January up to the mid of February and almost diminished on 16th
March on all wheat varieties / lines (Fig. 1).

Mean aphid population / five tillers were significantly different on some tested varieties / lines. The highest population was recorded on Sham6 and Aras, whereas the minimum aphid population was recorded on Skalmeje, Ritmo and Hereford.

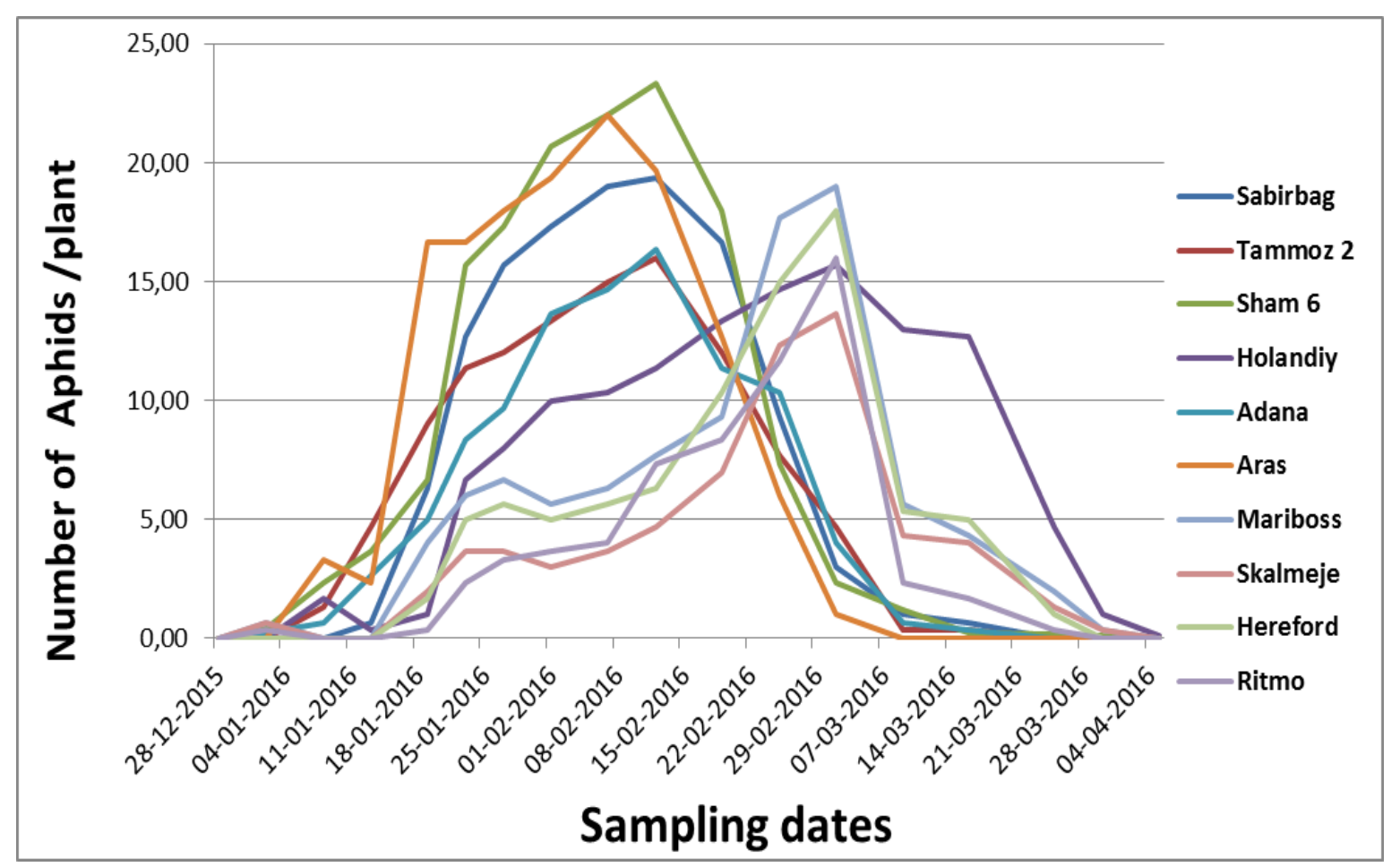

Fig. 1: The population trend of wheat aphids on different varieties/lines during 2015-2016.

On January 19, there was a gradual growth of the aphid population on most of the verities / lines. On February 7, maximum mean number of aphid found on Aras (20, 00), Sham6 $(16,33)$ and Sabir beg $(14,33)$, that were the highest number as compared to that on other varieties / lines. The minimum Aphid population were recorded on skalmeje and Ritmo that having non-significant difference among them in aphid population (Table 1).

Table 1. The reaction of ten winter wheat varieties to aphid infestation under different sowing dates.

\begin{tabular}{lllll}
\hline Varieties & \multicolumn{1}{l}{$\mathbf{D}^{\mathbf{1}}$} & $\mathbf{D}^{\mathbf{2}}$ & $\mathbf{D}^{\mathbf{3}}$ & \multicolumn{1}{l}{$\boldsymbol{p}_{\text {-value }}$} \\
\cline { 2 - 5 } & $\mathbf{2 8 - 1 1 - 2 0 1 5}$ & $\mathbf{1 9 - 1 2 - 2 0 1 5}$ & $0.00008 \mathrm{~d}$ & 0.00014 \\
\hline Skalmeje & $0.00009 \mathrm{~d}$ & $0.00007 \mathrm{~d}$ & $0.00020 \mathrm{~d}$ & 0.00009 \\
Hereford & $0.00021 \mathrm{~d}$ & $0.00023 \mathrm{~d}$ & $0.00017 \mathrm{~d}$ & 0.00006 \\
Ritmo & $0.00019 \mathrm{~d}$ & $0.00018 \mathrm{~d}$ & $0.00116 \mathrm{~d}$ & 0.00013 \\
Mariboss & $0.00120 \mathrm{~d}$ & $0.00118 \mathrm{~d}$ & $0.01667 \mathrm{a}$ & $<0.0001$ \\
Aras & $0.04889 \mathrm{~b}$ & $0.10000 \mathrm{a}$ & $0.02667 \mathrm{a}$ & $<0.0001$ \\
Sham6 & $0.04333 \mathrm{~b}$ & $0.06000 \mathrm{~b}$ & $0.03333 \mathrm{~b}$ & 0.01888 \\
Tammoz & $0.06667 \mathrm{c}$ & $0.02667 \mathrm{a}$ & $0.03000 \mathrm{~b}$ & $<0.0001$ \\
Adana & $0.05000 \mathrm{ab}$ & $0.03667 \mathrm{~b}$ & $0.05333 \mathrm{ab}$ & $<0.0001$ \\
Holandy & $0.03222 \mathrm{~b}$ & $0.02333 \mathrm{a}$ & $0.12333 \mathrm{a}$ & \\
Sabir beg & $0.09667 \mathrm{~b}$ & $0.15000 \mathrm{a}$ & & $<$ \\
\hline
\end{tabular}

Values with the same letter are not significantly different at $p \leq 0.05$. 


\section{Means with the same letter are not significantly different at $p \leq 0.05$}

In the beginning of $2^{\text {nd }}$ week of February, the gradual increase in temperature occurred and sharp increase in aphid population were recorded up to the mid of March. The temperature and relative humidity in which the aphid population increased were $9.5-26.5^{\circ} \mathrm{C}$ and $62-71 \%$ respectively. After the mid of March, the temperature and $\mathrm{RH}$ again increased but a sharp decrease in the aphid population was recorded. For all wheat varieties aphid infestations were greatest in the first sowing date and least in the second and third sowing dates.

On 3rd of March maximum population was recorded on Aras, Sham6 and Sabir beg followed by Holandy in descending order having significant difference among them in aphid population. The minimum population was recorded on Skalmeje, Ritmo and Hereford. On 16th March, Holandy had maximum population, which had significant difference $(p<0.0001)$ between each other in population.

There were no significant differences $(p<0.0001)$ among all four Danish wheat varieties to aphid infestation, while there were a significant differences among all Iraqi varieties the highest were for Sabir beg (0.12333) and Aras (0.10000). In case of first sowing date, the first aphid was observed in the $1^{\text {st }}$ week of January and the highest aphid population was observed in the second week of February /2016. At this stage the population of aphids was also high in the second sowing date but not maximum.

On weekly basis, statistical analysis shows highly significant differences present between aphid population densities in first and second sowing dates such as $(p<0.0001)$ for Aras, Sham6 and Sabir beg (Table 1). There were no significant differences present between Skalmeje and Ritmo in aphid populations of second and third sowing dates. Although the aphid population reduced with crop maturity, but remained in the plants until wheat crops were harvested.

\section{Effect of temperature, rainfall and relative humidity on aphid population density}

First detection of aphid on the wheat crops was observed on $2^{\text {nd }}$ of January 2016 (Table 2), at this time, the mean aphid population was $0.23 \mathrm{aphid} /$ plant, afterwards a gradual increase in aphid population were observed that reached to its peak in the mid of February (13.20 aphid/plant).

Table 2. Mean aphid population / plant of different sampling dates.

\begin{tabular}{cll}
\hline $\begin{array}{c}\text { Sl. } \\
\text { No. }\end{array}$ & Sampling dates & Population/Plant \\
\hline 1 & $28-12-2015$ & 0.00 \\
2 & $02-01-2016$ & 0.23 \\
3 & $08-01-2016$ & 0.93 \\
4 & $13-01-2016$ & 1.43 \\
5 & $19-01-2016$ & 7.70 \\
6 & $23-01-2016$ & 8.83 \\
7 & $27-01-2016$ & 10.00 \\
8 & $01-02-2016$ & 11.17 \\
9 & $07-02-2016$ & 12.27 \\
10 & $12-02-2016$ & 13.20 \\
11 & $19-02-2016$ & 11.90 \\
12 & $25-02-2016$ & 11.20 \\
13 & $02-03-2016$ & 9.73 \\
14 & $09-03-2016$ & 3.47 \\
15 & $16-03-2016$ & 3.11 \\
16 & $25-03-2016$ & 1.08 \\
17 & $30-03-2016$ & 0.29 \\
18 & $05-04-2016$ & 0.12 \\
\hline
\end{tabular}

The mean number of aphids per plant were higher on wheat line Aras (8.24), Shma6 (7.98), Sabir beg (7.74), Holandy (7.03), Adana (6.94) and Tammoz 2 (5.90), while the lowest aphid per plant were recorded on skalmeje (3.77), Ritmo (4.07), Mariboss (4.11) and Hereford (5.11). Aphid population started declining and on 25th of March 2016 (1.08 aphids/plant) were recorded. During April, the RH ranged from $23.08 \%$ to $18.67 \%$ and temperature from $26.5^{\circ} \mathrm{C}$ to $28.0^{\circ} \mathrm{C}$ maximum and from $13.5^{\circ} \mathrm{C}$ to $11.0^{\circ} \mathrm{C}$ minimum respectively (Fig. 2).

After mid of March, the population started declining and $0.12 \mathrm{aphid} /$ plant was observed in the 1st week of April and gradually no aphids were recorded on the wheat crops. Aphid infestation started mostly on the Leaves, spikes and later in mid of March also observed on stem.

\section{Population of Aphids on different varieties/lines of wheat and their thousand kernel weight}

The results of the present study showed that there were differences between verities in their reaction to aphid population (Table 3). The effect of aphid population on thousand kernel weight was significant difference $(p<0.0001)$ for the verities Aras and Sham6, whereas, not significant in the case of Skalmeje and Ritmo. There was a 
great effect of aphid population on Aras and Sham6, which showed much sensitive to aphid population.

Furthermore, there was no significant differences among sowing dates for Varieties Skalmeje and Ritmo whereas, there were a significant differences among sowing dates for varieties Aras, Sham6 and Sabir beg. Finally, there was a little difference among sowing dates on aphid population for varieties, Tammoz2, Adana, Holandy and Hereford Mariboss.

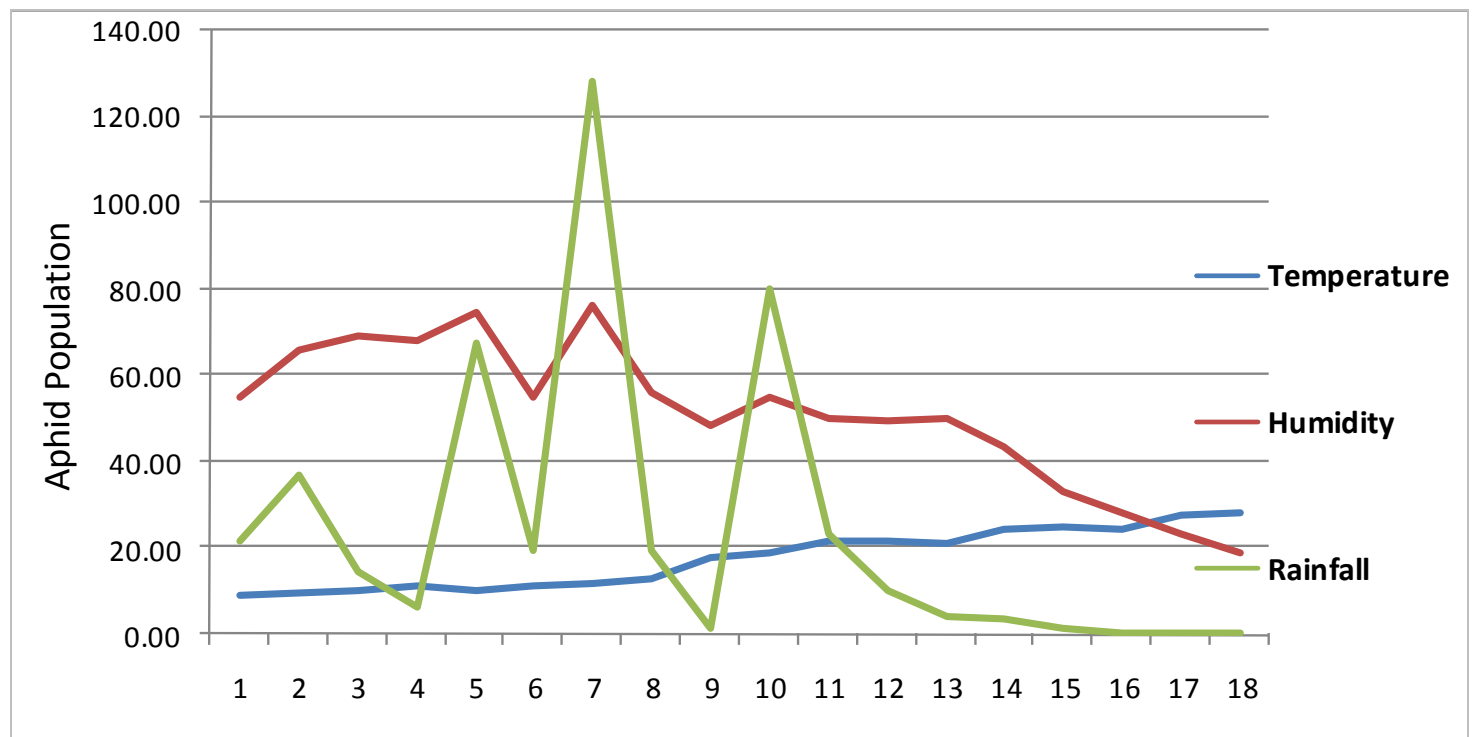

Fig. 2: The effect of relative humidity, rainfall and temperature on the aphid population density of wheat.

Table 3. Thousand kernel weights (g) in ten winter wheat cultivars tested under field condition in Bakrajo during 2015/2016.

\begin{tabular}{lllll}
\hline Cultivar & Sowing date 1 & Sowing date 2 & Sowing date 3 & $\boldsymbol{p}$-value \\
\hline Skalmeje & $1.9 \mathrm{~A}$ & $2.0 \mathrm{~A}$ & $2.2 \mathrm{~A}$ & 0.2038 \\
Ritmo & $1.5 \mathrm{~B}$ & $1.6 \mathrm{~B}$ & $1.7 \mathrm{~B}$ & 0.0169 \\
Mariboss & $1.6 \mathrm{~B}$ & $1.4 \mathrm{~B}$ & $2.2 \mathrm{~A}$ & 0.0066 \\
Hereford & $1.4 \mathrm{~B}$ & $2.0 \mathrm{AB}$ & $2.2 \mathrm{~A}$ & 0.0101 \\
Aras & $0.7 \mathrm{~B}$ & $2.0 \mathrm{~A}$ & $1.8 \mathrm{~A}$ & $<0.0001$ \\
Sham6 & $0.9 \mathrm{~B}$ & $1.8 \mathrm{~A}$ & $1.9 \mathrm{~A}$ & $<0.0001$ \\
Sabir beg & $1.2 \mathrm{~B}$ & $1.6 \mathrm{~A}$ & $1.7 \mathrm{~A}$ & 0.0078 \\
Holandy & $1.3 \mathrm{C}$ & $1.7 \mathrm{~B}$ & $2.1 \mathrm{~A}$ & $<0.0001$ \\
Adana & $1.3 \mathrm{~B}$ & $1.2 \mathrm{~B}$ & $2.9 \mathrm{~A}$ & $<0.0001$ \\
Tammoz2 & $1.5 \mathrm{~B}$ & $1.3 \mathrm{~B}$ & $2.8 \mathrm{~A}$ & $<0.0001$ \\
\hline
\end{tabular}

Means with the same letter are not significantly different at $p \leq 0.05$.

\section{Discussion}

Aphid infestation started in the 1st week of January and peaked in the latter half of February with fluctuations in population size thereafter up to mid of March. Our results are in conformity with (Gair et al., 1987), who observed that population of aphids in the field increased with the development of the wheat and peaked at the heading stage.

The aphid population increased gradually from 11th January to 22th February/ 2016 and remained low, because wheat crops were producing tillers in its early stage and aphid does not reproduce rapidly on the early growth stages of wheat (Acreman and Dixon, 1985). This may be due to the low quality of food available in the early stages of the wheat. Changes in quality and quantity of the food occur with life of the plant and its growth stages, which ultimately affect the survival, longevity, distribution, reproduction and speed of development of insects (Hinze and Daebery, 1976).

After 25th February, when wheat crops were in milk stage, the aphid population increased exponentially and reached its peak on 25th March. Our results confirm the results of earlier workers (Chander, 1996), who observed peak aphid population at milk stage, during the third week of March. 
Aphid reproduces rapidly and increases its population at heading or earing stage. This rapid growth in aphid population on all wheat varieties / lines could be due to availability of good of food present in the wheat crops (Zou et al., 1998). Another factor responsible for rapid increase in the aphid population is temperature (Wratten and Redhed, 1976). The present study results indicated that varieties Aras, Sham6 and Sabir beg were highly preferred by aphid population and no significant of differences among varieties skalmeje, and Ritmo.

Mean aphid population was higher (13.20 aphids/ plant) on first sowing date as compared to that on the second (10.19 aphids/ plant). The aphid population almost diminished on 5th April on all wheat varieties / lines when crop was at dough stage. These results are similar to those reported earlier by (Rossing et al., 1994; Chendar, 1996). Decline in population might be due to crop maturity, grain hardness, unavailability of sap due to senescence of the crop and high temperature (Chendar, 1996).

The damage per aphid was also higher during early anthesis than later (Wratten et al., 1979). The number of aphids increased at $15-18^{\circ} \mathrm{C}$ during earing and flowering of wheat. The highest population density was recorded during grain development and initiation of wax ripening. The decline in the aphid population could also be the result of the crop maturity. Chander (1996) reported that infestation of aphids on wheat crop is abundant during the heading and flowering stages and is reduced during the maturity stage of the crop. Temperature ranging from 7.7 to $25.2^{\circ} \mathrm{C}$ showed to be favorable for aphid growth (Chander, 1996), while the optimum temperature for aphid growth was $2^{\circ} \mathrm{C}$ to $44^{\circ} \mathrm{C}$ (Miller and Smith, 1998). The mean maximum temperature in region Bakrajo during February was $18.75^{\circ} \mathrm{C}$ and up to 25th March remained at $25.93^{\circ} \mathrm{C}$, which was favorable for the rapid aphid growth.

On 12th February, the maximum population was recorded on Sham6, Aras, and Sabir beg, which have a significantly different number of aphids / five tillers between them. The population was minimum, and nonsignificantly different $(p<0.0001)$ among them, on Skalmeje and Hereford. The mean maximum temperature after 16th March was $28^{\circ} \mathrm{C}$, which is higher than the favorable temperature for aphid growth. Manna (2002) found that average daily temperature and relative humidity play most important role in controlling aphid population in wheat field.
Weather conditions and initial Russian wheat aphid infestations may have affected the results of this study. The effect of maximum temperature and relative humidity had negative and significant effect on aphid population. Furthermore the effect of rainfall on aphid population was non-significant. Differences in the date of peak level and zero population may be due to the difference in the weather factors of different locations. Chendar (1996) confirmed that combination of all abiotic factors (temperature, humidity and rainfall) contribute a significant role in aphids population fluctuation on wheat.

Our results indicated that infestation by the aphid occurred on all wheat varieties with significant variation depending on sowing dates. The lowest infestation levels of aphid population were recorded on the Skalmeje, Ritmo and Hereford varieties in the first sowing date, while the highest infestation levels were record on Sham6, Aras and Sabir beg compared to the second at third sowing dates. TKW were not showed significant differences $(p<0.0001)$ for varieties Skalmeje and Ritmo compared varieties such as Aras and Sham6, which were affected by aphid population. Varieties, Aras and Sham6 showed to be susceptible to aphid population, whereas Skalmeje showed less susceptibility than other cultivars to infestation by aphid. Increasing in aphid population were from the lowest to the highest density decreased the number of grain per ear.

Most of the wheat varieties were noticed to be slightly resistant against aphids in case of late sowing trial and highly susceptible against aphids in early planting trial. Significantly high aphid infestation on early sown varieties has been reported. It has also been suggested that early maturing varieties would avoid outbreaks of aphids (Barabas and Benovsky, 1985).

\section{Conclusion}

It is clear from the results of the present study that wheat aphids started infesting wheat varieties in the second week of January. Maximum population was found during second week of February. Aphid population per five tillers was lowest on wheat variety Skalmeje and Ritmo and maximum Sham6 and Aras. Based on the number of aphid per five tillers it is concluded that varieties Skalmeje and Ritmo were most resistant, whereas Sham6 and Aras were most susceptible among the varieties tested in this study. We have observed the aphid population was high in the early sowing wheat 
crops and very low in late sowing, even lower than that on early sown crop.

From this research, it is concluded that early planting of wheat varieties can reduce aphid population below damaging level. It is recommended for the growers of winter wheat that late planting of varieties conditions may be adopted to reduce the aphid attack. This indicates that changing sowing date of wheat will affect aphid infestation. Preferably wheat in Bakrajo should be planted in the last week of October to avoid heavy aphid attack. Further studies should be directed on screening of verities sown at different dates, and effect of varying population of aphids on yield. Finally, the population of wheat aphids should be regularly monitored on different verities/lines. Aphid's tolerant/resistant cultivars/ varieties should be grown for reducing losses.

\section{Conflict of interest statement}

Authors declare that they have no conflict of interest.

\section{Acknowledgement}

The authors are thankful to Dr. Sidiq Aziz Sidiq, Department of Horticulture, Faculty of Agricultural Sciences, University of Sulaimani for providing an opportunity to carry out this study. The authors also like to thank Assistant Professor, Nariman Salih Ahmad for assistance with field work.

\section{References}

Acreman, T. M., Dixon., A. F., 1985. Developmental patterns in the wheat and resistance to cereal aphids. Crop Prot. 4(3), 322-328.

Barabas, L., Benovsky, J., 1985. The effect of winter wheat cultivars on the intensity of occurrence of the grain aphid (Sitobion avenae F). Ochrana Rostlin, 21(3), 195-199. [Wheat, Barley and Triticale Abstr. 3(3): Abstr. 5523, 1896].

Blackman, R.L., Eastop, V.F., 2000. Aphids on the World's Crops: An Identification and Information Guide. John Wiley \& Sons, Ltd., Chichester, UK.

Bowling, R.W., Wlide, G.E., Margolies, D., 1998. Relative fitness of greenbug (Homoptera: Aphididae) biotypes E and I on sorghum, wheat, rye and barley. J. Econ. Entomol. 91, 1219-1223

Brisson, J.A., Stern, D.L., 2006. The pea aphid, Acyrthosiphon pisum: An emerging genomic model system for ecological, developmental and evolutionary studies. Bioessays. 28, 747-755.

Burde, J. D., Porter, G., Puterka, S., Haley, Peairs, F., 2006. Biotypic variation among North American Russian wheat aphid (Homoptera: Aphididae) populations. J. Econ. Entomol. 99, 1862-1866.

Castro, G.B., 1980. Evaluation of wheat varieties to determine their resistance to aphids in E. I. Bajio. Agric. Tech. Mexico. 3, 176-177.

Chander, S., 1996. Aphid infestation of wheat in relation to climatic factors and predators. Ann. Pl. Protect. Sci. 4, 148-150.

Dixon, A. F. G., 1987. Cereal aphids as an applied problem. Agric. Zool. Rev. 2, 1-57.

Gair, R., Jenkins, J.E.E., Lester, E., 1987. Cereal Pests and Diseases $\left(9^{\text {th }}\right.$ Edn.). Farming Press Ltd., United Kingdom.

Girma, M., Wilde, G. E., Harvey, T. L., 1993. Russian wheat aphid (Homoptera: Aphididae) affects yield and quality of wheat. J. Econ. Entomol. 86, 594-601.

Godfray, H.C., Beddington, J.R., Crute, I.R., Haddad, L., Lawrence, D., Muir, J. F., Pretty, J., Robinson, S., Thomas, S. M., Toulmin, C., 2010. Food security: The challenge of feeding 9 billion people. Science. 27 (5967), 812-818.

Hays, D. B., Porter, R., Webster, J. A., Carver, B. F., 1999. Feeding behavior of biotypes $\mathrm{E}$ and $\mathrm{H}$ greenbug (Homoptera: Aphididae) on previously infested near-isolines of barley. J. Econ. Entomol. 92, 1223-1229.

Hinz, B., Daeber, F., 1976. Yield formation in winter wheat varieties influenced by the English grain aphid, Sitobium avenae (F). Arch. Phytopath. Pflenz. 12, 111-116.

Holmes, R.S., Burton, R.L., Burd, J.D., Ownby, J.D., 1991. Effect of greenbug (Homoptera: Aphididae) feeding on carbohydrate levels in wheat. J. Econ. Entomol. 80, 897-901.

Hussein, H.M., Al-neami, K. T., 2013. Laboratory study on the susceptibility of locally bread wheat cultivars to infestation by green bug. Iraqi J. Sci. 45, 856-861.

James, D.M., 2014. Perhaps the simplest of fruits are those of grasses (all cereals such as corn and wheat)... These fruits are caryopses. Botany. Jones \& Bartlett Publishers. 223p.

Kieckhefer, R.W., Gellner, J.L., 1992. Yield loss in winter wheat caused by low density cereal aphid population. Agron. J. Medison Wis. American Soc. Agron. 84, 180-183. 
Kindler, S . D, Elliot, N. C ., Giles, K . L., Royer, T. A., 2003 .Economic injury level for the green bug Schizaphis graminum, in Oklahoma winter wheat. Southwest. Entomol. 28, 163-166.

Kindler, S. D., Elliott, N. C., Giles, K. L., Royer, T. A., Fuentes, G. R., Tao, F., 2002. Effect of green bug (Homoptera: Aphididae) on yield loss of winter wheat. J. Econ. Entomol. 95(1), 89-95.

Kindler, S.D., Spomer, S.M., Harvey, T.L., Burlon, R.L., Staks, K.J., 1984. Status of biotype E greenbug (Homoptera: Aphididae) in Kansas, Nobrask. Oklahoma and Northern Texas during 1980-1981. J. Kansas Entomol. Soc. 57, 157-158.

Llewellyn, K.S., Loxdale, H.D., 2003. Migration and genetic structure of the grain aphid (Sitobion avenae) in Britain related to climate and clonal fluctuation as revealed using microsatellites. Mol. Ecol. 12, 21-34.

Loxdale, H.D., Tarr, I.J, Weber, C.P., Brookes, C.P., Digby, P.G.N., Castañera, P., 1985. Electrophoretic study of enzymes from cereal aphid populations. III. Spatial and temporal genetic variation of populations of (Sitobion avenae (F.) (Hemiptera: Aphididae). Bull. Entomol. Res. 75, 121-142.

Loxdale, HD, Hardie, J., Halbert S., Foottit, R., Kidd, N.A.C., Carter C.I., 1993. The relative importance of short and Long-range movement of flying aphids. Biol. Rev. 68, 291-311.

Manna, S. H., 2002. Cereal aphids on wheat in new valley, natural enemies, seasonal activity of alate forms and susceptibility of certain varieties to natural infestation. Assiut J. Agric. Sci. 31(2), 287-297.

Marzocchi, L., Nicoli, G., 1991. The principal pest of wheat. Principali Fitofagi de Frumento in Formatorl Fitopatologico 41(2), 29-33.

Miller, R. M., Smith, A. W., 1998. The greenbug aphid and its control. Fact Sheet, Extension Horticulture and Crop Sciences. Ohio State Univ. Ext. Fact Sheet. 2021 Coffey Rd., Columbus, Ohio 432101086.

Oakley, U.N., Ellis S.A., Walters, K.F.A., Watling, M., 1993. The effects of cereal aphid feeding on wheat quality: Cereal Quality III, Proceedings of Association of Applied Biologist, Churchill College Cambridge, UK.

Oerke, E.C., Dehne H.W, Schonbeck F., Weber, A., 1994. Crop production and crop protection: Etimated losses in major food and cash crops. Elsevier, Amsterdam.
Papp, M., Mesterhazy, A., 1993. Resistance to bird cherry-oat aphid (Rhopalosiphum padi L.) in winter wheat varieties. Euphytica. 67, 49-57.

Rios, D.E., Saluso, M.L.A., Conde, A.A., 1986. Evaluation of the damage caused to wheat by the grain aphid, Sitobion avenae. Serie Tecnica, Estacion Experimental Agropecuaria, Prana, Argentine, 53: 15

Robe, E.C., M.C., Westhuizen, P., Van Der Wewilt, M.C., Van Der Vesthuizen, Dervesthuizen, M., 1989. Aspects of the ecology of wheat aphid in South Africa. Phytophylactic. 21, 165-169.

Roberts, J. J., Foster, J. E., 1983. Effect of leaf pubescence in wheat on the bird cherry oat aphid (Hom.: Aphididae). J. Econ. Entomol. 76, 13201322.

Rossing, W.A.H., Daamen, R.A., Jansen, M.J.W., 1994. Uncertainty analysis applied to supervised control of aphids and brown rust in winter wheat. Part 2 . Relative importance of different components of uncertainty. Agric. Syst. 44(4), 449-460.

Simon, J.C., Baumann, S., Sunnucks, P., Hebert, P.D.N., Pierre, J.S., Le Gallic, J.F., Dedryver, C.A., 1999. Reproductive mode and population genetic structure of the cereal aphid Sitobion avenae studied using phenotypic and microsatellite markers. Mol. Ecol. 8:531-545.

Thomas, J. B., Butts, R. A., 1990. Effect of Russian wheat aphid on cold hardiness and winterkill of overwintering winter wheat. Can. J. Plant Sci. 70: 1033-1041.

Wains, M.S., Rehman, A., Latif, M., Hussain, M., 2008. Aphid dynamics in wheat as affected by weather and crop lanting time. J. Agric. Res. 46, 361-366.

William, B., 2015. USAD, Foregin Agricultura Service, Commodity Intelligence Report. January 12, 2015. baker@fas.usda.gov. International Production Assessment Division visit Crop Explorer http:/ww.gov/crop explorer/Default.aspx.

Wood, B.W., Tedders, W.L., Reilly, C.C., 1988. Sooty mold fungus on Pecan foliage suppresses light penetration and net photosynthesis. Hort. Sci. 23, 851-853.

Wratten, S. D., Redhead, P. C., 1976. Effects of cereal aphids on the growth of wheat. Ann. Appl. Biol., 84: 433-440.

Wratten, S.D., Lee, G., Stevens, D.J., 1979. Duration of cereal aphid populations and the effects on wheat yield and quality, Proceedings of the 1979 British 
Crop Protection Conference. Pests and Diseases, Vol.1.pp.1-8.

Xiong, C.J.,1990. Study on the relationship between the occurrence of Rhopalosiphum padi (L.) and the growing period of wheat. Insect Knowl. 27, 5-7.
Zou, Y. D., Men, S. D. Q., Geng, J. G., Chen, G., Wang, G. M., 1998. Influence of natural enemies on population of wheat aphid and greenbug. Chinese J. Appl. Entomol. 9(6), 613-616.

\section{How to cite this article:}

Sardar, S. A., Faraidun Muhammad, H. F., 2017. Effect of different sowing date on yield losses in ten winter wheat cultivars caused by aphid infestation. Int. J. Curr. Res. Biosci. Plant Biol. 4(3), 23-32.

doi: https://doi.org/10.20546/ijcrbp.2017.403.003 